\title{
MATTAMPUNG MASSAL DI DESA HARAPAN KECAMATAN TANETE RIAJA KABUAPATEN BARRU
}

\author{
${ }^{1}$ Nur Rahmi \\ ${ }^{1}$ Unversitas Negeri Makassar \\ Nurrahmi927@yahoo.com
}

\begin{abstract}
The results of this study indicate that: (1) The functions of the implementation of mattampung in Harapan Village besides continuing the habits of previous parents, mattampung also functions as a marker for subsequent generations in recognizing siblings or families who have already died. (2) mattampung massa is held once a year in October. After the decision of the adat council is obtained through a process of deliberation. Mass gathering is carried out by preparing betel nut and betel nut leaves, three chickens will be read to the next prayer in give to the customary leader and be taken to the tomb of the deceased person as food for the deceased because the community believes that when the deceased person has not been accommodated, they can still eat like a living person. (3) The values contained in the implementation of mattampung in social terms are the value of mutual cooperation, the value of wisdom or togetherness and the value of friendship. While in terms of the economy, the community is greatly helped by the existence of mass mattampung.
\end{abstract}

Keywords: Tradition, Mattampungmassal, Death Ceremony

\begin{abstract}
Abstrak
Hasil penelitian ini menunjukkan bahwa: (1) Fungsi dari di laksanakannya mattampung di Desa Harapan selain meneruskan kebiasaan orang tua terdahulu, mattampung juga berfungsi sebagai penanda untuk generasi-generasi berikutnya dalam menegenali anak saudara atau keluarga yang telah lebih dahulu meninggal. (2) mattampung massal dilaksanakan satu kali dalam satu tahun setiap bulan oktober.setelah adanya keputusan dari dewan adat yang didapatkan melalui proses musyawarah.mattampung massal dilaksanakan dengan mempersiapkan ayam kampong daun sirih dan buah pinang,ayam sebanyak tiga ekor akan di bacakan doa kemuadia di berikan kepada ketua adat dan dibawa ke makam orang yang telah meninggal sebagai makanan orang yang telah meninggal karena masyarakat mempercayai ketika orang yang telah meninggal belum ditampung maka masih bisa makan layaknya orang yang masih hidup. (3) Nilai-nilai yang terkandung dalam pelaksanaan mattampung dalam segi social adalah nilai gotong royong,nilai kearifan atau kebersamaan dan nilai silaturahmi. Sedangkan dalam segi ekonomi masyarakat sangat terbantu dengan adanya mattampung massal.
\end{abstract}

Kata kunci:Tradisi,Mattampungmassal, Upacara Kematian 


\section{Latar Belakang}

Masyarakat Kabupaten Barru memiliki berbagai macam kebudayaan yang sampai sekarang masih sangat dijaga oleh masyarakat setempat. Masyarakat Kabupaten Barru memiliki banyak sekali arti dalam setiap tindakan yang akan dilakukan dalam kehidupan sehari-harinya. Hal ini sering dikaitkan oleh masyarakat Barru dengan nilai,norma,dan kaidah-kaidah yang berlaku dalam setiap tindakan dalam kehidupan sehari-harinya. Sehingga masyarakat Kabupaten Barru banyak memiliki Tradisi yang berkaitan langsung dengan kehidupan sehari-harinya.

Kebudayaan sudah menjadi pedoman kehidupan dan pola hidup pada masyarakat,maka masyarakat selalu mempertahankan kebudayaan yang dimiliki. Pada masyarakat kabupaten Barru mempertahankan kebudayaan sama halnya mempertahankan pedoman hidup yang telah mereka lakukan sejak zaman nenek moyang. Desa Harapan kecamatan Tanete Riaja merupakan salah satu desa yang berada di wilayah Kabupaten Barru.Masyarakat Desa Harapan merupakan masyarakat yang sampai sekarang masih mempertahankan kebudayaannya, karena kebudayaan yang sudah ada dianggap sakral.

Desa Harapan merupakan Desa terakhir yang ada di Kabupaten Barru . Letak Desa Harapan yang berda di pelosok Kabupaten Barru membuat masyarakat Desa Harapan hidup dalam system social budaya tersendiri. Membuat masyarakat Desa Harapan memiliki tradisi yang berbeda dengan masyarakat pada umumnya.Masyarakat Desa harapan memiliki tradisi-tradisi tertentu yang berbeda dengan masyarakat sekitar.

Tradisi yang masih dipertahankan oleh masyarakat Desa Harapan adalah tradisi kematian.Tradisi ini dilakaukan oleh masyarakat Desa Harapan yang ada di Kabupaten Barru.Tradisi tersebut dianggap sebagai kebudayaan masyarakat Desa Harapan dan memiliki makna tersendiri bagi masyarakat setempat.Bagi masyarakat Desa Harapan Tradisi kematian harus tetap dilakukan agar nantinya orang yang sudah meninggal mendapat tempat terbaik di akhirat.Tradisi tersebut biasa disebut dengan Mattampung Massal.Tradisi Mattampung massal biasa dilakukan satu kali dalam satu tahun setelah kepergian orang yang telah meninggal.Tradisi ini dilakaukan satu kali dalam satu tahun karena, masyarakat Desa Harapan mempercayai bahwa dalam waktu satu tahun setelah 
meninggal almarhum masih memerlukan bekal serta makanan dan minuman.Tradisi Mattampung massal ini dilakukan di waktu yang khusus yang telah ditentukan masyarakat Desa Harapan itu sendiri. Kegiatan Mattampung massal ini dilakukan dengan memasangkan batu nisan secara bersamaan pada kuburan orang yang telah meninggal dalam kurun waktu satu tahun.

Tradisi kematian yang dilaksanakan di Desa Harapan berbeda dengan tradisi kematian yang dilakukan oleh masyarakat Kabupaten Barru pada umumnya. Jika pada masyarakat Kabupaten Barru pada umumnya dalam tradisi kematian dilakukan dengan pemberian doa, pemandian jenazah, menguburkan,tahlilan, dan yang terakhir pada hari ketujuh Mattampung (pemasangan batu nisan). Hampir sama dengan tradisi yang dilakukan oleh masyarakat kabupaten Barru pada umumnya namun terdapat perbedaan yang sangat mencolok diantaranya. Di Desa Harapan Mattampung dilaksanakan bukan pada saat tujuh hari pasca meninggal namun dilakukan dalam satu tahun setelah orang tersebut meninggal.Hal inilah yang menjadikan mattampung di Desa Harapan disebut dengan Mattampung massal karena dilaksanakan dalam waktu yang bersamaan. Dalam kurun waktu satu tahun tersebut makam tidak didiamkan begitu saja, sanak keluarga akan berkunjung untuk membawakan makanan dan minuman beserta peralatan makan lainnya. Karena, masyarakat Desa Harapan masih memperrcayai bahwa orang yang telah meninggal sebelum dilaksanakan Mattampung masih bisa untuk makan dan minum layaknya manusia yang masih hidup.

Dengan adanya perbedaan tradisi kematian yang dilakukan masyarakat Desa Harapan dengan masyarakat Kabupaten Barru pada umumnya menjadikan ketertarikan penulis untuk melekaukan penelitian mengenai tradisi kematian yang di lakukan oleh masyarakat Desa Harapan. Perbedaan tradisi yang dimiliki oleh masyarakat Desa Harapan dengan masyarakat Kabupaten Barru pada umumnya menjadikan masyarakat terkadang masih sulit mebedakan makna dari tradisi kematian Mattampung yang dilaksanakan di Desa Harapan dan di Kabupaten Barru secara Umumnya. Penelitian ini dimaksudkan agar seluruh masyarakat mengetahui bahwa ada tradisi Mattampung massal di Desa Harapan Kecamatan Tanete Riaja Kabupaten Barru dan masyarakat dapat melihat tradisi ini sebagai salah satu budaya yang harus tetap dilestarikan. 
Berdasarkan latar belakang yang telah diuraikan diatas, peneliti tertarik untuk melakukan penelitian tradisi kematian pada masyarakat Desa Harapan Kecamatan Tanete Riaja Kabupaten Barru. Adapun judul penelitian yang diangkat oleh peneliti adalah "Mattampung Massal di Desa Harapan Kecamatan Tanete Riaja Kabupaten Barru"

Berdasarkan pemaparan latar belakang di atas, maka rumusan masalah dalam penelitian ini adalah:

1. Mengapa Tradisi Mattampung Massal masih tetap di laksanakan oleh masyarakat Desa Harapan Kecamatan Tanete RiajaKabupaten Barru?

2. Bagaimana gambaran pelaksanaan Tradisi Mattampung Massal di masyarakat Desa Harapan Kecamatan Tanete Riaja Kabupaten Barru?

3. Nilai-nilai apa yang terkandung dalam pelaksanaan TradisiMattampung Massaldi Desa Harapan Kecamatan Tanete Riaja Kabupaten Barru?

Metode penelitian yang digunakan dalam penelitian ini adalah observasi, wawancara dan dokumentasi,Dalam penelitian ini yang menjadi informan adalah masyarakat, ketua adat, kepala Desa, dan Imam setempat.

\section{Pembahasan}

\section{Gambaran Umum Lokasi Penelitian}

Pada tahun 1961 Desa Harapan berasal dari Desa Lajoangin, yang di nahkodai Oleh Bapak DG. KAMBO selama 3 tahun dan pada tahun 1964 di adakanlah pemilihan Kepala Desa yang pertama yang terpilih pada saat itu adalah Bapak H. MALIK. R dari Kelurahan Lompo Riaja beliau memimpin selama 24 tahun namun menjelang 2 tahun kepemimpinannya Menrong dan tompo lemo-lemo keluar dari wilayah Desa Libureng sehingga Kepala Desa yang terpilih yaitu H. MALIK.R menggabungkan wilayah tersebut ke Desa Lajoangin dan pada saat itupula Desa Lajoangin Di Rubah Namanya menjadi Desa Harapan dalam artian bahwa "Masyarakat selalu berharap selalu ada Harapan Kedepan yang lebih baik" dan Kantor Desa pun di pindahkan Ke Tompo lemo-lemo kemudian Pada tahun 1989 diadakan pemilihan Kepala Desa yang ke Dua kalinya dan terpilih pada saat itu H. ARIF.HALIM yang juga berasal dari Kelurahan 
Lompo Riaja beliau memimpin Harapan selama 10 tahun (Dokumen Rencana Pembangunan Jangka Menengah Desa (RPJMD) Tahun 2017).

Desa Harapan terbentuk karena dianggap perlu adanya pemekaran Desa disebabkan Desa Libureng pada saat itu memiliki jangkauan wilayah terlalu luas sehingga tata kelola Pemerintahan,Pembangunan,serta Pelayanan dan pengawasan Pemerintah Desa sulit terjangkau,awalnya dibentuklah Persiapan Pemekaran Desa dengan menamakan Desa Persiapan Lajoangin ,setelah menjadi Desa Devinitif dinamakanlah Desa Harapan ,dikatakan Desa Harapan karena awalnya desa ini Cuma 4 Dusun yaitu Dusun Menrong,Dusun Lajoangin,Waruwue ,Dusun Ammerung dan Dusun Ampiripada tahun 1994 terjadi lagi pemekaran Desa yaitu Desa Harapan terbagi 2 yaitu Desa Harapan dan Desa Bacu-Bacu sehingga 2 Dusun terpisah dari Desa Harapan kemudian masuk menjadi Wilaya Desa Bacu-Bacu sehingga Desa Harapan tinggal 4 Dusun yang menjdi wilayah binaannya:

Adapun Luas Wilayah Desa Harapan adalah 53.10 Ha Dengan Batas Wilayah Yaitu:

Sebelah Utara : Desa Anabanua

Sebelah Selatan : Desa Bacu-Bacu

Sebelah Timur : Desa Gattareng Kab. Soppeng

Sebelah Barat : Desa Libureng

Wilayah Desa Harapan terangkum dalam wilayah Kecamatan Tanete Riaja Pada tahun 1961Desa Harapan terletak di Daerah Wilayah Kecamatan Tanete Riaja dengan luas Wilayah 53.10 Ha/M2.Desa Harapan terdiri dari 6 Dusun, 19 RT, Kecamatan Tanete Riaja Kabupaten Barru. Dengan batas wilayah di Sebelah utara berbatasan dengan Desa Anabanua kecamatan barru. Sebelah selatan berbatasan dengan Desa Bacu-bacu Kecamatan Pujanannting, sebelah timur berbatasan dengan Desa gattareng Kecamatan Marioriwawo Kabupaten Soppeng, dan sebelah barat berbatasan dengan Desa Libureng Kecamatan Tanete Riaja (Dokumen Rencana Pembangunan Jangka Menengah Desa (RPJMD) Tahun 2017).

\section{Fungsi Mattampung Massal di Desa Harapan Kecamatan Tanete Riaja Kabupaten Barru}


Segala bentuk tradisi yang di tinggalkan oleh nenek moyang terdahulu memiliki fungsi dan nilai-nilai yang terkandung didalamnya.Seperti halnya dengan Mattampung massal juga memiliki fungsi yang masih tetap dijaga oleh masyarakat Desa Harapan Kabupaten Barru.

Setiap tradisi memiliki fungsi bagi masyarakatnya, begitupun tradisi mattampung juga memiliki fungsi-fungsi tertentu bagi masyarakat.Fungsi dari di laksanakannya mattampung di Desa Harapan selain meneruskan kebiasaan orang tua terdahulu, mattampung juga berfungsi sebagai penanda untuk generasi-generasi berikutnya dalam menegenali anak saudara atau keluarga yang telah lebih dahulu meninggal.

Pelaksanaan mattampung di Desa Harapan Kecamatan Tanete Riaja Kabupaten Barru tidaklah memakan biaya yang banyak seperti yang dilakukan pada masyarakat Kabupaten Barru pada umumnya. Karena di Desa Harapan ketika akan dilaksanakan mattampung masyarakat berbondong-bondong mendatangi rumah orang yang akan melakukan acara. Masyarakat datang dengan membawa berbagai keperluan yang akan di gunakan dalam mattampung seperti semen, uang, kayu bakar, beras dan peralatan lainnya. Hal ini menunjjukkan dalam pelaksanaan mattampung massal masyarakat tidak terbebani melainkan dapat meringankan beban yang melaksanakan mattampung massal ini.

\section{Gambaran Pelaksanaan tradisi Mattampung massal di Desa Harapan Kecamatan Tanete Riaja Kabupaten Barru}

Mattampung, adalah salah satu tradisi yang dilakukan setelah ada orang meninggal dunia di masyarakat dilakukan salah satu cara untuk memperingti hari kematian seseorang sebelum diberikan batu nisan di kuburan orang yang meninggal dunia,dengan melakukan serangkaian acara yang sudah menjadi ketentuan dari nenek moyang mereka ${ }^{1}$.

Mattampung adalah tradisi peninggalan nenek moyang mereka yang tidak bias untuk di tinggalkan karena sudah menjadi wasiat untuk warga Desa Harapan yang telah di pegang teguh dan menjadi kewajiban untuk setiap masyarakat untuk melaksanakannya sebagai bentuk penghormatan bagi nenek moyang mereka dan

${ }^{1}$ Dra. Wiwik P. Yusuf. Op.Cit. Hlm 12 
karena kepercayaan yang mereka pegang teguh bahwa tradisi yang telah diwariskan dari nenek moyang wajib untuk dijaga dan terus dilanjutkan hingga generasi -generasi berikutnya. Karena mereka meyakini dan sudah pernah mereka alami apabila ada tradisi yang mereka lewatkan atau tinggalkan oleh satu masyarakat setempat maka akan terjadi sesuatu kepada mereka. Masyarakat setempat mempercaya jika mereka tidak melaksanakan tradisi tersebut maka biasanya aka nada yang jatuh sakit dan jika dibawa ke dokter penyakitnya akan susah disembuhkan. Maka dari itu masyarakat mnyimpulkan jika mereka sakit itu adalah akibat dari mereka meninggalkan tradisi mereka.

\section{a. Waktu pelaksanaan Mattampung massal}

Mattampung massal di laksankan bukanlah semata-mata dilaksanakan pada saat kita mau.Mattampung massal di Desa Harapan dilaksanakan pada waktu yang telah ditentukan dalam kurun waktu satu kali dalam satu tahun.Mattampung yang dilaksanakan di Desa Harapan Kecamatan Tanete Riaja kabupaten Barru biasanya dilaksanakan pada bulan 10 setelah seluruh rangakaian kegiatan masyarakat selesai.Mattampung di Desa Harapan juga disebut acara akhir tahun karena pelaksanaanya yang dilakukan paling akhir. Di Desa Harapan masyarakat melaksanakan kegiatan mulai dari menanam padi,panen padi, pesta panen, naik rumah, pesta pernikahan setelah semua itu rampung baru dilaksanakan mattampung karena semua kegiatan tidak bisa di laksnakan secara bersamaan jika satu tradisis di laksnakan maka tradisi lain tdak bisa dilaksanakan. Semuanyaa hanya dapat dilaksnakan pada waktunya. Jika waktunya sudah lewat maka tidak dapat dilaksanakan lagi.

\section{b. Tata cara Mattampung}

Tata caramattampung, biasanya sebelum memasuki acara mattampung terlebih dahulu masyarakat setempat berbondong-bondong mendatangi rumah kepala adat (orang yang di tuakan dan mengerti tentang Adat) dengan membawa beras sekitar satu liter atau lebih untuk dibawa ke rumah kepala adat sebelum musyawarah dimulai. Sambil menunggu masyarakat berdatangan untuk musyawarah dan mendengar keputusan ketua adat.Biasanya mereka membuat beberapa rekko ota untuk dibaca lalu 
dibawa ke posi bola ${ }^{2}$. Kemudian setelah sebagian besar masyarakat sudah berada di rumah ketua adat maka acara musyawarah baru akan dimulai dengan beberapa tokoh masyarakat yang hadir di tempat musyawarah lalu diumumkanlah hasil musyawarah yang telah dilaksanakan. Setelah itu ketua adat memrintahkan seluruh masyarakat yang hadir untuk diam dan mendengarkan keputusan ketua adat. Setelah musyawarah selesai barulah masyarakat mengetahui tradisi-tradisi yang akan dilaksanakan dalam satu tahun termasuk tradisi Mattampung kapan dilaksanakan.

Tata cara mattampung dilaksanakan dengan mempersiapkan berbagai macam persiapan . mattampung dilakukan setelah masyarakat setempat semuanya telah massokko yang biasanya dilakukan setelah panen sawah dan setelah semua acara dilaksanakan seperti acara maccera' bola (syukuran rumah), pernikahan, dsb. Setelah semua acara tersebut selesai dilaksanakan maka barulah tradisi Mattampung itu dimulai. Adapun tata cara mattampung sebagai berikut :

1. Keluarga mempersiapkan ayam kampong sebanyak 3 ekor untuk dipotong.

2. kemudian, satu ekor ayam dipersembahkan kepada arwah yang telah meninggal,

3. satu ekor ayam dipersembahkan untuk pembaca, dan satu ekor ayam dipersembahkan kepada ketua adat selaku orang yang memberi arahan sampai tradisi mattampung itu selesai.

4. Setelah ayam selesai dipotong lalu dibawa kekuburan untuk dibaca oleh ketua adat.

5. Ini dilakukan selama tujuh hari berturut-turut sampai hari ketujuh pada saat makam akan dipasangkan batu nisan ${ }^{3}$.

Dalam acara mattampung selama tujuh hari atau satu minggu berturut-turut orang yang telah meninggal diberikan makanan atau biasa disebut ipalengeng andrena karena menurut pemahaman masyarakat setempat bahwa selama orang yang telah meninggal belum ditampung maka arwah orang yang telah meninggal tersebut masih bisa makan dan minum seperti halnya kita yang masih hidup.Maka dari itu keluarga

\footnotetext{
${ }^{2}$ Posi bola atau pusat rumah merupakan titik tengah dalam membangun rumah yang sering digunakan oleh masyarakat setempat melakukan pengajian atau pembacaan doa.

3I Suge.masyarakat Dusun Lemo."Wawancara".'Di Dusun Lemo Desa Harapan Kecamatan tanete Riaja kabupaten Barru. 2 April 2019
} 
arwah tersebut memberikan makanan di piring dan minuman Sampai acara mattampung selesai.

\section{c. Masyarakat yang boleh terlibat dalam pelaksanaan Mattampung Massal}

Dalam pelaksnaan mattampung yang paling penting itu adalah sanak keluarga karena keluargalah yang menyiapkan segalanya yang di butuhkan dalam acara tersebut seperti menyiapkan ayam kampong, daun sirih,dan daun pinang yang akan di model untuk diberi doa oleh panre guru atau ketua adat. Yang terlibat juga dalam acara tersebut adalah panre guru yang akan mengarahkan keluarga yang meninggal dunia apa-apa yang akan dibutuhkan nantinya pada saat pelaksanaan Mattampung massal, masyarakat setempat beserta tetangga kampong juga ikut berpartisipasi dalam membantu pelaksanaan mattampung massal terutama pada saat pemasangan batu nisan karena dalam jumlah banyak. Masyarakat setempat tidak hanya membantu dalam pemasangan batu nisan namun masyarakat juga membantu dengan memberikan beras kepada keluarga yang akan melaksanakan mattampungmassal ini . nantinya pada saat pelaksanaan mattampung tuan rumah di bantu oleh masyarakat sekitar akan membuat kue yang akan dimakan oleh tamu yang datang dalam pelaksanaan mattampung massal tersebut.

\section{Nilai-nilai yang terkandung dalam pelaksanaan} Tradisimattampung massal di Desa Harapan Kecamatan Tanete Riaja

\section{Kabupaten Barru}

Mattampung dilaksanakan dengan cara satu kali dalam satu tahun merupakan hal yang berbeda dengan pelaksanaan mattampung pada umumnya di Kabupaten Barru. Keberdaan mattampung massal di Desa Harapan menyimpan keunikan tersendiri.Namun masyarakat Desa Harapan sangat mengapresiasi mattampung massal ini karena dengan adanya mattampung massal solidaritas antar masyarakat dapat terbangun, dan rasa tolong menolong serta kekeluargaan dapat terbangun dengan baik. Masyarakat selama ini juga tidak pernah merasa dirugikan dengan adanya mattampung massal karena dengan mattampung massal semua yang dikerjakan akan terasa ringan karena dikerjakan oleh banyak orang.

Adapun nilai- nilai yang terkandung dalam dalam pelaksanaan mattampung Massal sebagai berikut: 


\section{a. Nilai Gotong Royong}

Hubungan yang terjadi antar masyarakat dengan masyarakat yang lain di Desa Harapan kurang harmonis. Karena seringnya ada perasangka-perasangka buruk yang timbul antar warga desa.Akan tetapi dengan adanya pelaksannan mattampung setiap tahunnya dapat memicu keharmonisan yang terjadi pada masyarakat Desa Harapan.Dalam pelaksanaan mattampung nilai-nilai gotong royong sangat dijunjung tinggi. Karena masyarakat setempat sangat menjunjung tinggi sikap toleransi dan tolong menolong yang tidak semua masyarakat di daerah lain dapat kita jumpai seperti di Desa Harapan. Nilai gotong Royong pada saat pelaksanaan mattampung sangatlah tinggi setelah waktu mattampung sudah ditentukan maka masyarakat akan mendatangi rumah keluarga yang akan melaksanakan mattampung. Bagi laki-laki akan datang membantu mengumpulkan kayu bakar yang nantinya akan digunakan memasak. Sedangkan perempuan datang dengan membawa beras untuk dimasak nantinya pada saat acara Mattampung dilaksanakan.

Didalam tradisi diatur bagaimana manusia berhubungan dengan manusia lain atau satu kelompok manusia dengan kelompok lain. Bagaimana manusia bertindak terhadap lingkungannnya dan bagaimana perilaku manusia terhadap alam dan yang lain norma yang sekaligus mengatur penggunaaan saksi dan ancaman terhadap pelanggaran dan penyimpangan $^{4}$

Nilai-nilai gotong royong pada masyarakat Desa Harapan sangat tampak dengan pelaksanaan segala kegiatan masyarakat di Desa Harapan yang terstruktur ${ }^{5}$.

Dengan terstrukturnya kegiatan yang dilaksanakan di Desa Harapan maka masyarakat dapat hadir seluruhnya dan membantu secara suka rela tampa mengharapkan imbalan seperti yang terjadi di Kabupaten Barru pada umumnya.

b. Nilai Kearifan dan Kebersamaan

Manusia sebagai makhluk social yang tidak bisa hidup sendiri.Manusia akanselalu membutuhkan kebersamaan dalam hidupnya. Dalam pelaksanaan mattampung semua masyarakat menjadi sama dan tidak ada yang dibeda-bedakan.

${ }^{4}$ Nur Hakim. Op.Cit Hlm.7

${ }^{5}$ Kegiatan yang dilaksanakan di Desa Harapan terstruktur dimulai dari menanam padi, panen padi, pesta panen, acara pernikahan, acara naik rumah, dan yang terakhir acara mattampung yang biasa disebut acara akhir tahun. 
Menurut masyarakat setempat masyarakat saling berbaur satu sama lain karena menurut pandangan masyarakat bahwa cepat ayau lambat mereka akan mengalami kematian dan pasti akan membutuhkan orang lain juga.

Jika dikaitkan dengan teri maka selaras dengan teori identitas dimana teori ini Teori identitas sosial dipelopori oleh Henri Tajfel pada tahun 1957 dalam upaya menjelaskan prasangka, diskriminasi, perubahan sosial dan konflik antar kelompok. Menurut Tajfel (1982), social identity adalah bagian dari konsep diri seseorang yang berasal dari pengetahuan mereka tentang keanggotaan dalam suatu kelompok sosial bersamaan dengan signifikansi nilai dan emosional dari keanggotaan tersebut. Identitas sosial berkaitan dengan keterlibatan, rasa peduli dan juga rasa bangga dari keanggotaan dalam suatu kelompok tertentu.Lewat teori ini, peneliti mampu menganalisis bagaimana pentingnya identitas dalam sebuah kelompok masyarakat

c. Nilai menjalin silaturahmi

Dalam pelaksanaan mattampung silaturahmi saling terjaga kerena masyarakat saling mengabari antara masyarakat satu dengan masyarakat lainnya agar turut hadir dalam pelaksanaan mattampung tersebut.masyarakat pun hadir untuk membantu keluarga yang melaksanakan acara. Dalam berbagai kegiatan yang dilaksanakan oleh masyarakat pada dasarnya diketahui oleh warga desa karena pada saat kegiatan atau acara akan di laksanakan maka yang membuat acara akan menyampaikan kepada anggota masyarakat yang lainya.

\section{Kesimpulan}

Berdasarkan hasil pebahasan dalam penelitian yang telah dilakukan, maka penulis berkesimpulan bahwa.

1. Tradisi mattampung Massal merupakan upacara tradisional yang dilaksanakan masyarakat untuk mengormati orang ang telah mendahului kita. Mattampungdilaksanakan dengan tujuan agar masyarakat atau sanak keluarga dapat mengetahi anggota keluarganya yang lebi dahulu meninggal. Mattamppung juga betujuan untuk memudahkan generasi berikutnya dalam mengetahui keluarganya yang telah meninggal bukan hanya sekdar meneruskan apa yang telah dilakukan orang tua terdahulu. 
2. Pelaksannan mattampung massal dilaksanakan pada bulan oktober atau biasa disebut acara akhir tahun karena dilaksnakan di akhir tahun dan di laksnakan paling terakhir karena di Desa Harapan pada umumnya setiap pekerjaan dilaksnakan berdasarkan waktunya Karena semuanya memiliki struktur tertentu. Mattamppung tidak dapat di campur baurkan dengan acara lain seperti pertanian, selamatan rumah, dan pernikahan . masyarakat terlebih dahulu melakukan penanman padi setelah selesai penanaman padi masuk ke panen padi dan pesta panen, baru setelah dilaksnakan pesta panen selamatan rumah baru bisa dilaksnakan setelah selesai selamatan rumah baru dilaksnakan acara pernikahan dan yang terakhir baru acara mattampung setelah mattampung sudah dimulai maka kegiatan pertanian, selamatan rumah, dan pernikahan tidak bisa dilaksanakan lagi.

Dalam pelaksanaan mattampug banyak yang perlu dipersiapkan masyarakat seperti ayam kampong daun sirih dan daun pinang yang akan di baca oleh ketua adat. Dan keluargalah yang akan memepersiapkannya maka dari itu orang yang terlibat dalam pelaksnaan mattampung ini adalah keluarga dan ketua adat yang akan memberikan arah kepada keluarga yang akan di tamping serta masyarakat yang akan membantu dalam pelaksanaan mattampung massal ini.

3. Mattampung juga memiliki nilai-nilai yang terkandung didalammnya yang menjadikan masyarakat sampai saat ini masih mempertahankannya nilai-nilai yang terkandung dalam mattampung masal diantaranya

1. Nilai gotong royong

2. Nilai kearifan dan kebersamaan,dan

3. Nilai menjalin silaturahmi

Masyarakat Desa Harapn dalam pelaksnaan mattampung juga tidak mengganggu perekonomiannya justru dengan pelaksnaan mattampung massal perekonomian yang melaksnakan mattampung cukup terbantu dengan adanya bantuan dari masyarakat samapai mattampung itu selesai. Masyarakat akan datang membawa beras serta uang dan orang yang akan melaksnaan mattampung akan melakukan patungan untuk membeli perlengkapan yang akan digunakan dalam mattampung. Jumlah uang yang dikumpulkan pun tidak ditentukan masyarakat hanya mengumpulkan semampunya saja. 
Adapula sumbangan dari warga karena dilain sisi perempuan akan membawa beras sedangkan laki-laki akan membawa amplop serta kayu bakar jadi pekerjaan akan semakin ringan dan perekonomian terbantu.

Jadi dalam pelaksanaan mattamppung banyak terkandung nilai dan fungsi serta banyak membantu perekonomian masyarakat.Mattampung massal juga perlu melibatkan keluarga dan ketua adat yang memberi arahan.Masyarakat juga sangat antusias dalam pelaksnaan mattampung secara massal karena dapat memudahkan pekerjaan mereka.

\section{A. Saran}

a. Bagi Pemerintah

a. Implementasi pasal 32 tentang kebudayaan agar kiranya dilaksanakan secara sungguh-sungguh sehingga budaya lokal yang juga merupakan budaya nasional tetap terjaga kelestariaannya.

b. Merupakan rekomendasi bagi pemerintah dalam memberikan perhatian penuh dalam upaya-upaya penelitian selanjutnya.

c. Mempertimbangkan kebijakan-kebijakan daerah dalam upaya mempertahankan budaya lokal.

b. Bagi Masyarakat

a. Agar kiranya budaya yang sudah berkembang di dalam masyarakat selama ini dijaga dan dilestarikan sebagai salah satu pilar budaya nasional.

b. Diera globalisasi sekarang ini, masyarakat harus lebih keritis terhadap budaya asing yang akan masuk ke dalam budaya lokal dengan melakukan filterasi sehingga nilainilai luhur yang terkandung didalam budaya lokal tidak terkikis oleh kemajuan zaman.

c. Bagi peneliti

Sebagai refrensi kepada peneliti selanjutnya untuk lebih mendalamii tradis Mattampung massal di Desa Harapan Kecamatan Tanete Riaja Kabupaten Barru.

\section{Daftar Pustaka}

Yusuf Wiwik P. dkk.1993.Upacara Tradisional (upacara kematian) Sulawesi Selatan.Makassar:BPNB.

Rahmat K.H Jalaluddin.2006.Memaknai Kematian. Bandung: Pustaka II Man

Nurhakim Moh .2003. Islam Tradisional dan Reformasi pragmatisme”agama dan pemikiran hasan Hanafi “. Malang: Bayu Medra Publishing. 